\title{
Geographic Ancestry and Cause-specific Mortality in a National Population
}

\author{
Jan Saarela $\cdot$ Fjalar Finnäs
}

Received: 13 June 2007 / Accepted: 6 February 2008/Published online: 6 May 2008

(C) Springer Science+Business Media B.V. 2008

\begin{abstract}
There are marked differentials in mortality risks across regions in Finland. No exhaustive explanation to this variation has been provided, however. The aim of this paper is to analyse how geographic ancestry, as proxied by persons' birth region and population group, interrelates with cause-specific mortality risks. Focusing on people aged between their mid-thirties and late-forties, we use longitudinal population register data that offer opportunities to account for variables that represent both persons' social background and their own social status at young adult age. Results of Cox proportional hazard models say that these variables have substantial effects on mortality of different causes, but only a marginal impact on the variation in death rates by birth region and population group. The geographic mortality pattern is found to be specifically prominent for causes of death that are fairly unrelated to persons' lifestyles. Our findings suggest that genetic predisposal as expressed in terms of geographic ancestry might play a relevant role in understanding mortality variation within the population of Finland.
\end{abstract}

Keywords Birth regions · Population groups · Cause-specific mortality · Finland

\section{Introduction}

It is well documented that people of the two main population groups, Finnish speakers and Swedish speakers, differ in life expectancy (Sauli 1979; Valkonen et al. 1992; Koskinen 1994; Martelin 1994; Koskinen and Martelin 2003). Finnishspeaking men are expected to live 3 years shorter and Finnish-speaking women 1 year shorter than their Swedish-speaking counterparts (Saarela and Finnäs 2006).

\footnotetext{
J. Saarela $(\bowtie) \cdot$ F. Finnäs

Abo Akademi University, P.O. Box 311, 65100 Vasa, Finland

e-mail: jan.saarela@abo.fi
} 
Both groups are indigenous and have equal constitutional rights. What is so specific in the Finnish case still is that those constituting the minority in numbers, the Swedish speakers who amount to barely $6 \%$ of the total population, have lower death risks. Their mortality levels are about the same as those of people in the neighbouring countries Sweden and Norway.

The population-group mortality gradient in Finland is particularly marked between ages 35 and 50 years, during which Finnish-speaking men have almost twice higher death risk than Swedish-speaking men (Fig. 1). In women in the same ages, the excess mortality of Finnish speakers is around $40 \%$. In these ages nonnatural causes of death contribute to a large proportion of all deaths (Table 1). Alcohol-related mortality (alcohol-related diseases and alcohol poising) amounts to almost a fifth of all male deaths, and suicides and all other external causes, respectively, to about equally many. Alcohol is still involved also in many of the deaths caused by external causes (Lunetta et al. 2001). As compared with younger ages, cardiovascular diseases become more common and account for about a quarter of all male deaths in the age group 45-49 years. In women, the number of deaths is very low in these ages, but for mortality due to diseases other than cardiovascular (primarily neoplasms), the number of deaths is about as many as for men, which explains their large share of all female deaths in the age group. In higher ages diseases play a more important role. Factors that underlie mortality variation consequently manifest in different ways over the age span, which makes it is necessary to undertake analyses of cause-specific deaths on short age intervals.

In spite of the great interest devoted to understand why the two population groups differ in mortality, no satisfactory explanation has yet been provided. In principle, there may be three main contributors with varying impact in different ages: socioeconomic and other environmental circumstances, cultural factors that impact on

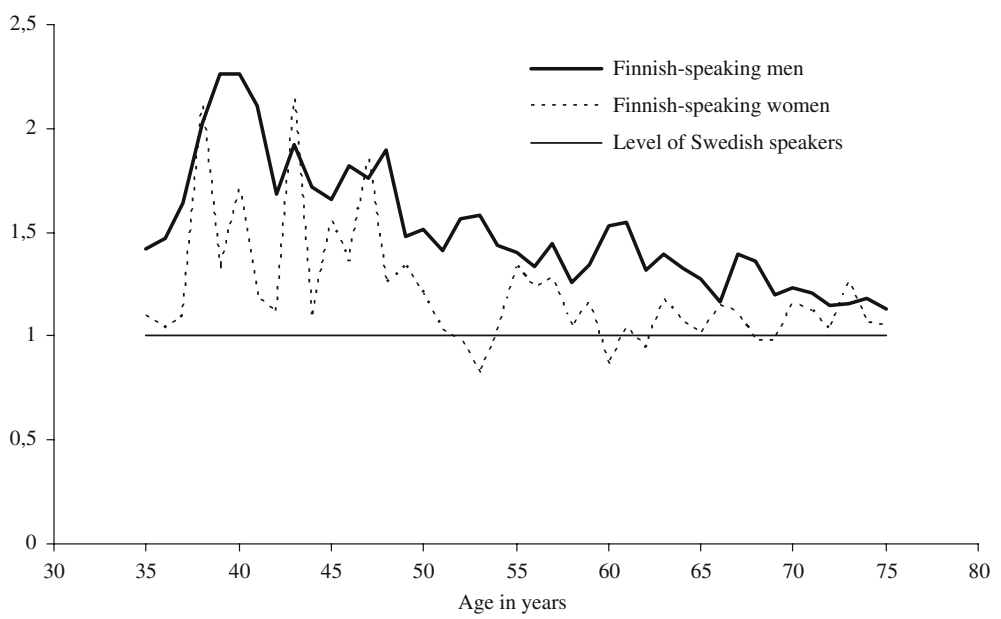

Fig. 1 Age-specific death rates of Finnish speakers in relation to those of Swedish speakers, 1995-2005. Source: Authors' calculations based on Statistics Finland (2007a, b, c) 


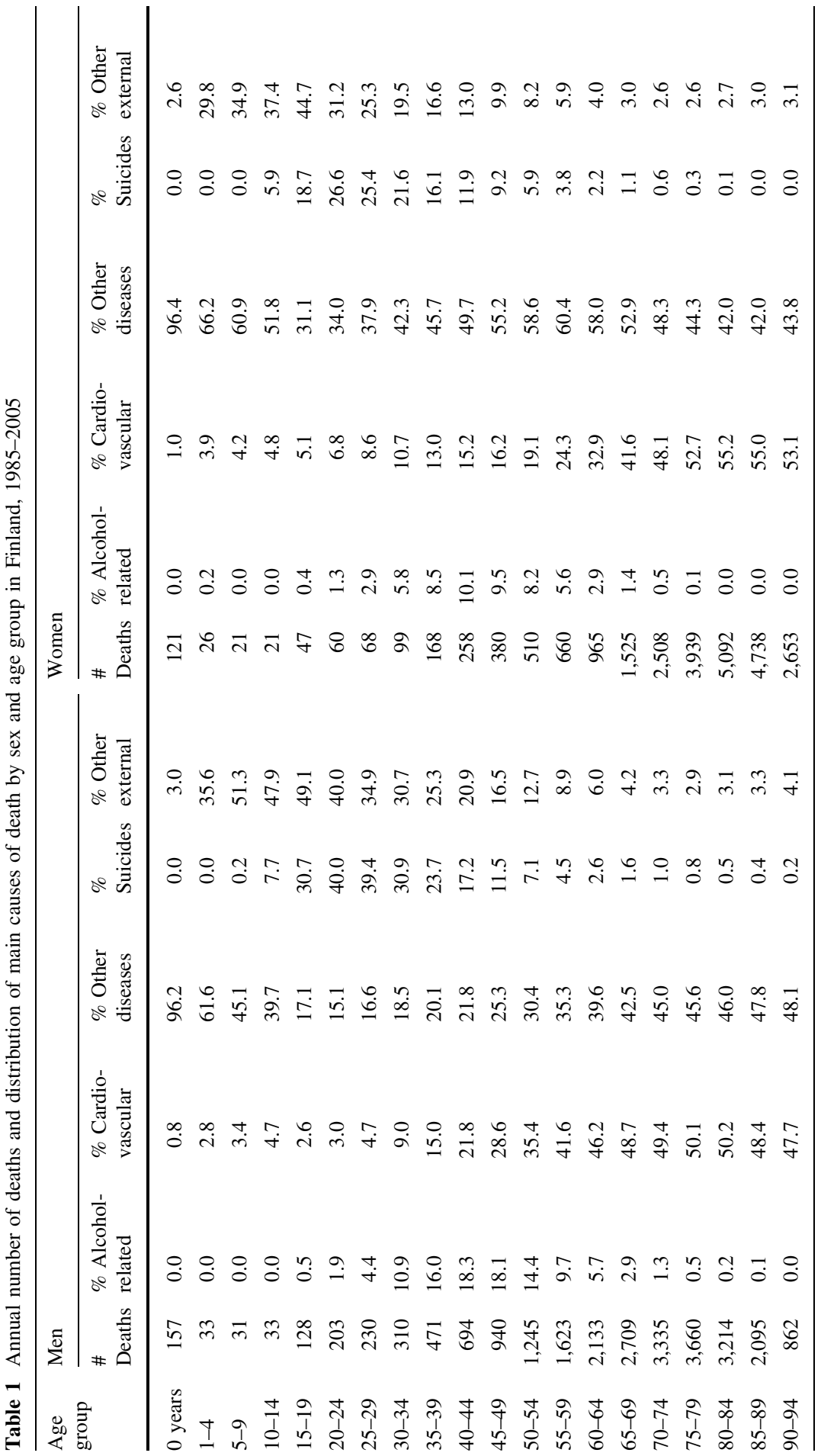




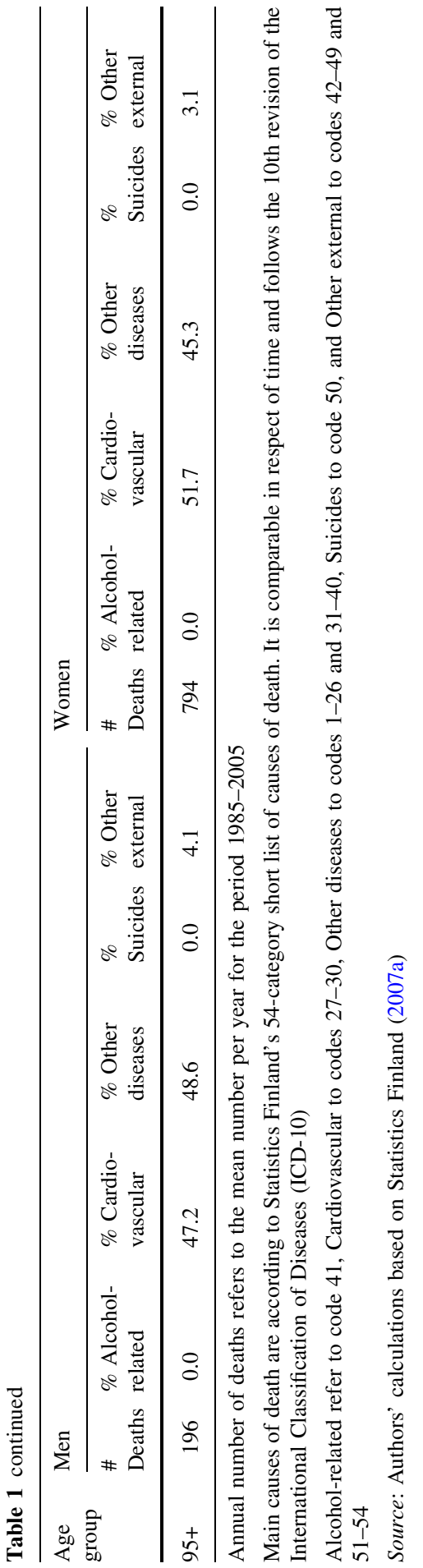


health behaviours and exposure to risky lifestyles, and variation in the heritability of genetic propensities (cf. Koskinen and Martelin 2003).

To some extent the two population groups differ on socio-economic characteristics, but particularly in men such variation has still been found accounting for only a minor part of the mortality differential (Saarela and Finnäs 2005a, b).

Little is known about population-group differences in health behaviours and exposure to risky lifestyles. With regard to alcohol consumption, it has been argued that Finnish speakers have less healthy drinking habits than Swedish speakers (Simpura 1990), which also is supported by findings which say that Finnishspeaking men in working ages have twice higher risk of alcohol-related mortality than Swedish-speaking men (Blomgren et al. 2004). However, there is no exhaustive study that explicitly compares the two groups with regard to risk factors for health.

Results of blood group analyses indicate that Swedish speakers differ from Finnish speakers with regard to geographic ancestry (Kajanoja 1972; Eriksson 1973; Sahi 1974; Eriksson et al. 1986; Virtaranta-Knowles et al. 1991). This fits into the knowledge of how the country was inhabited according to archaeological and historical data (Workman et al. 1976; Norio 2003). The ancestors of the Swedish speakers came from Western Europe, as Finland was a part of Sweden until 1809, whereas Finnish speakers inhabited the country predominantly from the East. No study has established a direct relationship between the population-group mortality differential and variation in specific genetic markers, however.

To understand mortality variation in Finland, we argue that population-group differentials should be understood and analysed together with geographic differentials in mortality (cf. Saarela and Finnäs 2008). Like in many other countries, such as e.g. Germany and the United Kingdom (Langford and Bentham 1996; Luy 2004), there is a geographical mortality pattern also in Finland. In the Finnish case, death rates have a tendency to increase in the South-West to North-East direction (Koskinen and Martelin 1994; Pitkänen et al. 2000). This pattern is not fully consistent across sexes and all main causes of death (see Fig. 2), but it clearly signals that mortality variation within the country is highly interrelated with geographic confounders. Like the case with the population-group mortality differential, the geographic variation in death rates has not been sufficiently understood and can principally be related to the same latent factors.

In spite of a substantial decrease in overall death rates in Finland during past decades, relative mortality differentials across regions and population groups have remained very much the same (Saarela and Finnäs 2006). Furthermore, the coastal regions, where death rates are clearly the lowest, have for centuries been settled by the Swedish speakers. All this makes it reasonable to suspect that not only current environmental circumstances are important, but also that more long-term factors are involved. This is confirmed by research which says that persons' birth region correlate highly with their mortality risks, even when account is taken for present region of residence (Valkonen 1987; Saarela and Finnäs 2006, 2008). Whether this reflects regional differences in socio-economic and social circumstances at childhood or some other latent factors, such as variation in genetic predisposal or cultural factors, is not clear. 
Fig. 2 Relative differentials across provinces in mortality of all causes and main causes of death in ages 35-49 years. Notes: Calculations are based on official statistics for the total population in Finland aged 35-49 years in 1985-2005 (Statistics Finland 2007a, b). Each bar gives mortality in a province in relation to the national average (which is equal to 1). All numbers are standardised for age and observation year. Provinces as referred to by the labels on the $x$-axes correspond with those on the map. The bars represent the 20 provinces in Finland, with a separate category for the Helsinki metropolitan area (the municipalities Helsinki, Vantaa, Espoo and Kauniainen). On the map in the figure, the provinces are numbered in an order that roughly go in the South-West to North-East direction. Labels on the $x$-axes are in this spatial order and thus correspond with those on the map. The bars are coloured in order to increase readability with regard to how we categorise these provinces into larger regions in the analyses to come (see the next chapter)

In this paper we use individual-level longitudinal register data linked to mortality records in an attempt to adjudicate between these two explanations. Unlike previous studies concerned with working-aged people, we explicitly control for circumstances at childhood. The data come from population registers, so there are no missing observations and no individual recall bias. For the ages under studypeople aged between their mid-thirties and late-forties-we can include cohorts for which there is information about persons' socio-economic and social background, as well as about their own social status at adult age. Thus we account not only for variables that reflect present circumstances, but also use fairly good proxies for the situation at childhood as observed at the individual level. Both sets of variables can be assumed important predictors of cause-specific mortality as they reflect both direct social and economic effects and indirect effects that work via health behaviours and hazardous lifestyles. Since certain causes of death are more related to health behaviours and lifestyles than others, separating main causes of death will help to understand the potential role of any cultural related factors. Given this, our primary aim is to analyse how geographic ancestry, in terms of each person's birth region and population group, interrelates with cause-specific mortality variation within the population of Finland.

Due to some specific circumstances a person's birth region in combination with her population group can be considered a reasonably good proxy for geographic ancestry. During past centuries, and particularly the latest, migration flows in Finland have mainly gone from the East and the North towards the Southern parts of the country, including the Helsinki metropolitan area. These population shifts have predominantly been undertaken by Finnish speakers. Swedish speakers in Finland have always lived along the coast, and they have had very low internal migration rates. Most of their internal migration has been in the direction of the Helsinki metropolitan region (Korkiasaari and Söderling 1994; Saarela 2006). These circumstances have resulted in the situation, that Finnish speakers born in the interior regions of the country, and Swedish speakers in the coastal region outside the Helsinki area, represent geographic rather stable subgroups of the population. Hence, people born in regions from which the large part of all internal migration has taken place can on fairly reasonable grounds be assumed representing the descendants of persons who have lived there for many generations. This is the case for Swedish speakers born in the Coastal area, as well as Finnish speakers born in Northern Finland, in Eastern Finland, and in Western Finland excluding the Coastal area.

The data and methodology is presented in greater detail in the next chapter. 


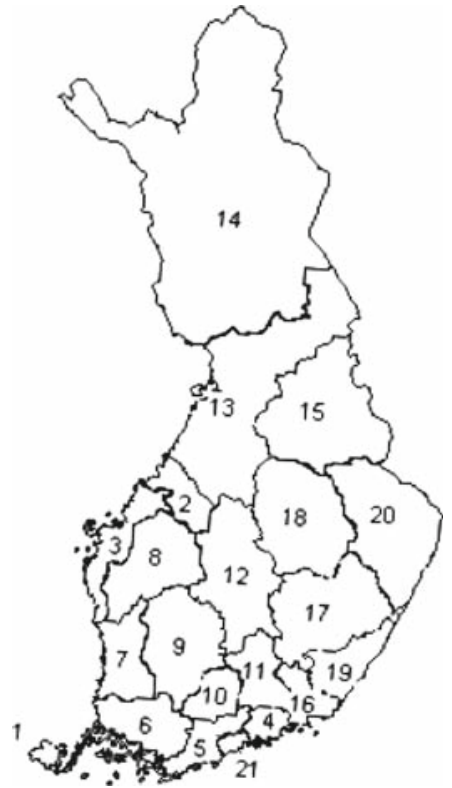

Map of Finland indicating the provincial borders, with a separate category for the Helsinki area (21).

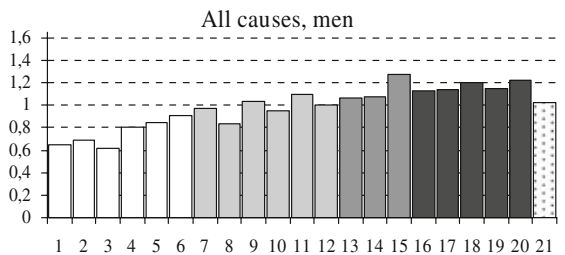

Alcohol-related causes, men

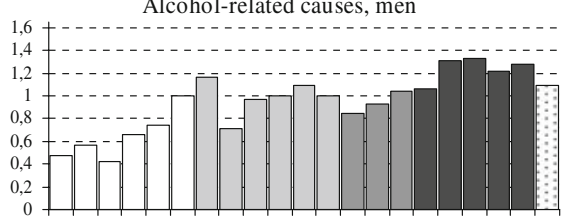

$1 \quad 2 \quad 3 \quad 4 \quad 5 \quad 6 \quad 7 \quad 8 \quad 9 \quad 101112131415161718192021$

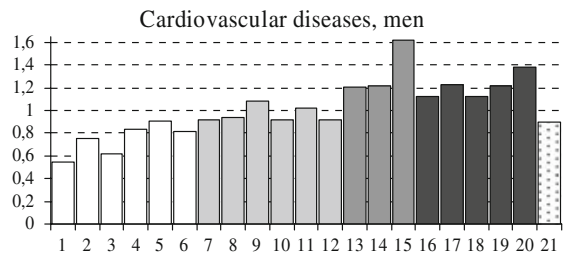

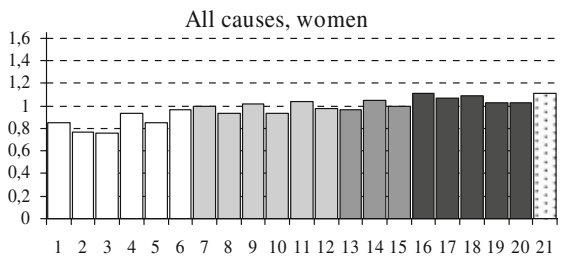

Alcohol-related causes, women

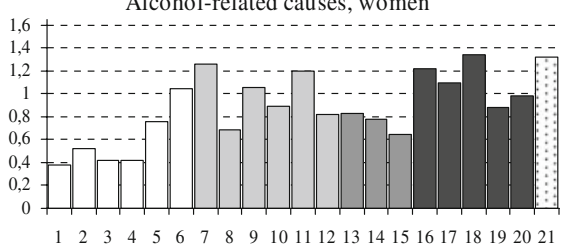

Cardiovascular diseases, women

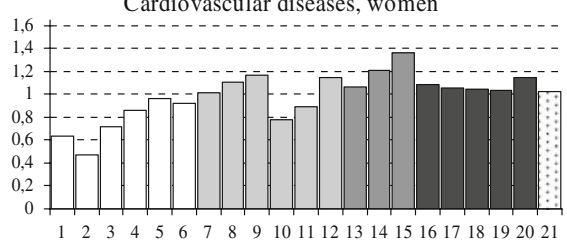

\section{Data and Methodology}

The data come from the longitudinal census data file compiled by Statistics Finland (2007d). It consists of linked individual information for all Finnish residents from the 

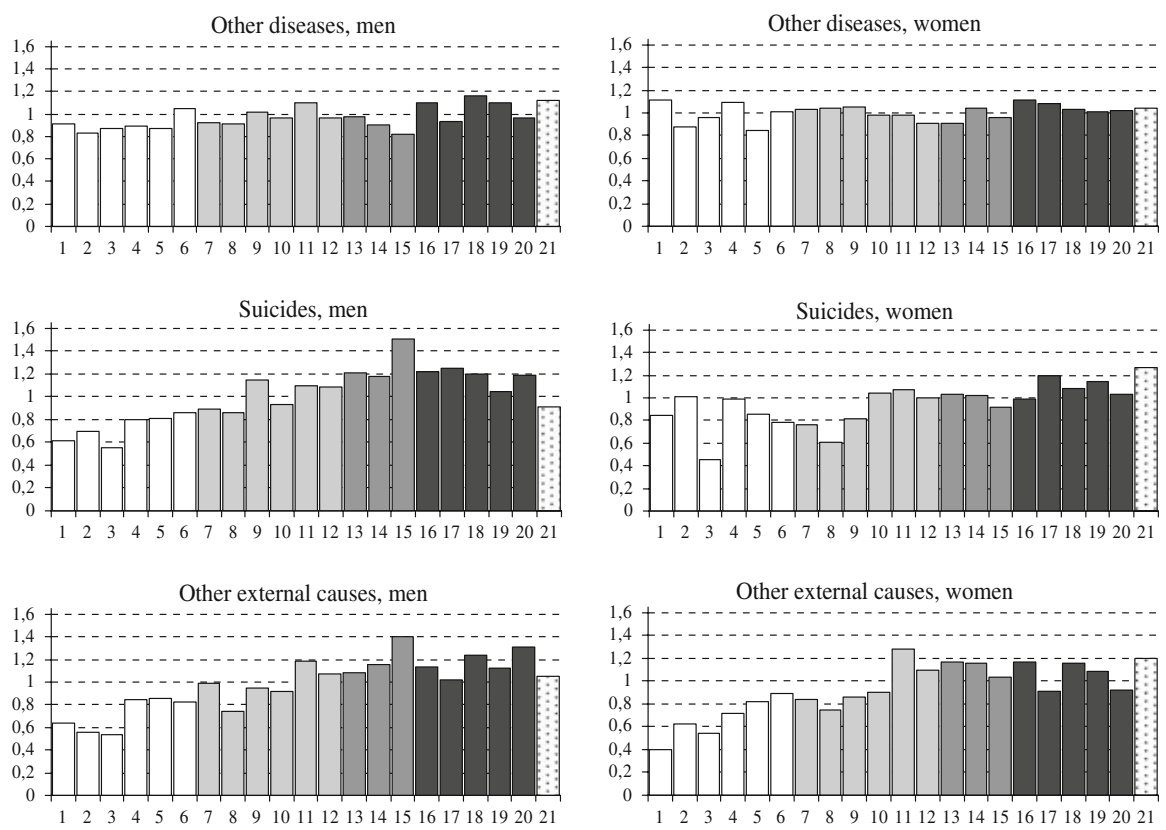

Fig. 2 continued

censuses of 1970, 1975, 1980, 1985, 1990, 1995 and 2000. The version used here is a stratified random sample, comprising $50 \%$ of all Swedish speakers and $5 \%$ of all Finnish speakers. In the population register, on which the data are based, people in each group can be separated according to their unique mother. Due to confidentiality reasons, it was not possible to obtain a larger sample. Our data include information about each person's population group, sex, year of birth, birth region, and variables related to socio-economic position and family conditions. They are discussed below.

For each individual, the data have been complemented with information about the event of death. If the person had died before 2005, we know in which year and the cause according to 10 main categories (see the footnotes of Table 1). The taxonomy means that age-specific death risks can be estimated at the single-year level for a reasonably short age interval. Therefore, we use Cox proportional hazard models, where age provides the baseline function (starting at age 35), and each variable of interest enters as a time-invariant covariate. Persons who migrate abroad are treated as right-censored observations.

Our study covers the ages 35-48 years, in which the differential in all-cause mortality between the population groups is the widest. Given that both social background and own status is of interest, we can include the cohorts born 1956-1969 into the analysis. Men are of primary interest, but parallel analyses are undertaken for women as well. Year of birth is included to capture variation in mortality over calendar time.

In total we use information on 72,851 individuals and 889 deaths. Since there were few deaths in specific categories we were forced to merge some of the 10 main ones. For men, we therefore perform analyses of mortality due to (1) Alcohol-related 
causes, (2) Cardiovascular diseases, (3) Other diseases, (4) Suicides, and (5) Other external causes, respectively. For women we can in practice separate only between mortality due to diseases other than cardiovascular (referred to as Other diseases) and mortality of all the other causes of death (referred to as Other causes).

The variables utilised to reflect living conditions in the parental home-socioeconomic status, homeownership, family type and number of siblings-are all commonly used in register-based studies on social background and mortality (Pensola 2003). They are measured at the latest census before age 15, i.e. when the person was 10-14 years of age. The situation at these ages thus serves as a proxy for conditions throughout whole childhood.

Socio-economic background measures parental social class, according to the position of the head of the household (usually the father), by distinguishing children of (1) Upper-level white-collar workers, (2) Lower-level white collar workers, (3) Blue-collar workers, (4) Self-employed, and (5) Others. The two latter are fairly heterogeneous in character. With regard to Homeownership background we distinguish persons who come from families renting their accommodation and those raised in families owning their dwelling. As only a quarter of all households in Finland belong to the former category, the variable should primarily be seen as an additional indicator of socio-economic conditions, within social class. Family background separates people who were living with both parents from all others. Number of siblings distinguishes between persons who lived without any sibling, with one, with two, or with more than two siblings (in the same household). Each of the variables can be assumed associated with mortality of different causes of death through material, behavioural as well as psychological mechanisms.

Own social status, as measured by educational level, marital status and unemployment experience, are known to be highly correlated with various causes of mortality at working ages (Pensola 2003). Educational level reflects the situation at age 30-34 years, whereas marital status and unemployment experience are summary measures for the ages 20-24, 25-29 and 30-34 years of age, respectively. The first one distinguishes people with (1) Primary, (2) Secondary, (3) Lowest tertiary, (4) Lower-degree tertiary and (5) Higher-degree tertiary education. Marital status separates people (1) with a partner, i.e. those who are married or live in consensual unions, (2) who previously had a partner, and (3) who never had a partner. Unemployment experience distinguishes people according to whether they have (1) not been unemployed whatsoever, (2) been unemployed (registered as a jobseeker) at some time during one of three census years, and (3) been unemployed at some time during more than one of three census years.

All three variables may be highly selective with respect to health and mortality, which means that people with poor health have worse opportunities for obtaining higher education, for marriage, and for becoming and remaining employed, than others (Bartley 1994; Hu and Goldman 1990; Martikainen and Valkonen 1996). We will not devote any interest to the causality problem involved, but rather treat these variables as broadly reflecting variation in social circumstances at young adulthood. It is essential to note, however, that own social status generally correlates with social background (Pensola 2003). Accounting for one subset of variables will therefore likely reduce the estimated effects of those in the other markedly. 
The spatial distribution of each population group together with the geographic mortality differentials (discussed in the previous chapter) imply that we construct a new variable that combines population group and birth region. Its categories, which are illustrated on the map in Fig. 3, are (1) Swedish speakers in the Coastal area, (2) Finnish speakers in the Coastal area, (3) Finnish speakers in Western Finland, (4) Finnish speakers in Northern Finland, (5) Finnish speakers in Eastern Finland, (6) Swedish speakers in the Helsinki area, and (7) Finnish speakers in the Helsinki area. The whole settlement area of the Swedish speakers, except for the Helsinki area, is considered to be one region (cf. Fig. 1). Less than $3 \%$ of the Swedish speakers live elsewhere in Finland, and they are excluded from this analysis.

Table 2 gives distributions of the variables that represent persons' social background and own social status according to this geographical categorisation. As can be seen, there is in many instances large variation across the geographic subgroups, and the Helsinki area in particular is evidently very different from the others. When considering that these variables can be assumed highly correlated with health and mortality, it is essential to include them into the analysis, and to separate the Helsinki area.

Fig. 3 Map of Finland showing the geographic categorisation applied in the analysis. Note: The Coastal area represents a smaller spatial region than that given by the six first provinces referred to in Fig. 2. This category has been constructed with the purpose of facilitating a more refined analysis, as it includes only municipalities that have substantial Swedishspeaking settlement

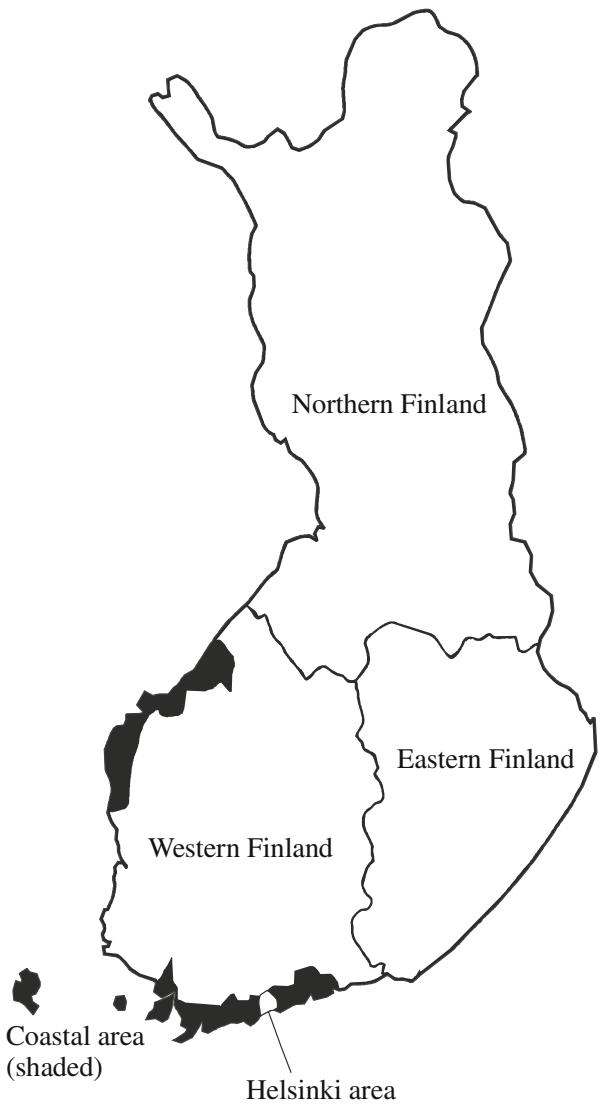


Table 2 Variable distributions by population group and birth region (\%)

\begin{tabular}{|c|c|c|c|c|c|c|c|}
\hline & $\begin{array}{l}\text { Swedish } \\
\text { speaker } \\
\text { Coastal } \\
\text { area }\end{array}$ & $\begin{array}{l}\text { Finnish } \\
\text { speaker } \\
\text { Coastal } \\
\text { area }\end{array}$ & $\begin{array}{l}\text { Finnish } \\
\text { speaker } \\
\text { Western } \\
\text { Finland }\end{array}$ & $\begin{array}{l}\text { Finnish } \\
\text { speaker } \\
\text { Northern } \\
\text { Finland }\end{array}$ & $\begin{array}{l}\text { Finnish } \\
\text { speaker } \\
\text { Eastern } \\
\text { Finland }\end{array}$ & $\begin{array}{l}\text { Swedish } \\
\text { speaker } \\
\text { Helsinki } \\
\text { area }\end{array}$ & $\begin{array}{l}\text { Finnish } \\
\text { speaker } \\
\text { Helsinki } \\
\text { area }\end{array}$ \\
\hline \multicolumn{8}{|l|}{ Socio-economic background } \\
\hline Blue-collar worker & 33.0 & 46.9 & 45.2 & 41.0 & 43.4 & 21.8 & 39.8 \\
\hline $\begin{array}{l}\text { Lower-level white-collar } \\
\text { worker }\end{array}$ & 16.9 & 14.6 & 14.1 & 12.5 & 12.6 & 27.9 & 23.5 \\
\hline $\begin{array}{l}\text { Upper-level white-collar } \\
\text { worker }\end{array}$ & 10.7 & 8.8 & 8.1 & 6.7 & 6.0 & 37.3 & 23.6 \\
\hline Self-employed & 34.0 & 22.8 & 25.2 & 28.5 & 28.4 & 6.5 & 6.5 \\
\hline Other & 5.4 & 6.9 & 7.4 & 11.3 & 9.7 & 6.6 & 6.6 \\
\hline \multicolumn{8}{|l|}{ Homeownership background } \\
\hline Yes & 75.4 & 68.9 & 70.4 & 76.6 & 70.2 & 58.1 & 54.3 \\
\hline No & 24.6 & 31.1 & 29.6 & 23.4 & 29.8 & 41.9 & 45.7 \\
\hline \multicolumn{8}{|l|}{ Family background } \\
\hline Both parents & 91.3 & 86.4 & 87.9 & 88.7 & 88.6 & 83.9 & 81.3 \\
\hline One parent and others & 8.7 & 13.6 & 12.1 & 11.3 & 11.4 & 16.1 & 18.7 \\
\hline \multicolumn{8}{|l|}{ Number of siblings } \\
\hline 0 & 36.4 & 34.0 & 30.7 & 20.8 & 26.6 & 41.1 & 41.2 \\
\hline 1 & 13.1 & 13.8 & 13.6 & 8.7 & 10.4 & 18.4 & 19.6 \\
\hline 2 & 28.4 & 26.7 & 25.1 & 23.8 & 26.5 & 27.9 & 24.2 \\
\hline $3+$ & 22.1 & 25.5 & 30.5 & 46.7 & 36.5 & 12.6 & 15.1 \\
\hline \multicolumn{8}{|l|}{ Educational level } \\
\hline Primary & 26.0 & 25.1 & 21.5 & 17.4 & 20.9 & 21.3 & 28.2 \\
\hline Secondary & 43.4 & 47.5 & 50.5 & 54.7 & 53.4 & 33.2 & 41.4 \\
\hline Lowest tertiary & 14.2 & 13.6 & 13.7 & 14.7 & 13.6 & 14.0 & 12.7 \\
\hline Lower-degree tertiary & 6.5 & 6.5 & 5.5 & 5.7 & 5.3 & 9.4 & 5.1 \\
\hline Higher-degree tertiary & 9.9 & 7.4 & 8.8 & 7.5 & 6.7 & 22.2 & 12.5 \\
\hline \multicolumn{8}{|l|}{ Marital status } \\
\hline With partner & 69.2 & 66.2 & 65.6 & 66.0 & 64.1 & 67.9 & 61.6 \\
\hline Previously with partner & 6.3 & 11.1 & 10.9 & 10.2 & 10.4 & 11.4 & 14.3 \\
\hline Never with partner & 24.6 & 22.6 & 23.5 & 23.9 & 25.5 & 20.6 & 24.1 \\
\hline \multicolumn{8}{|l|}{ Unemployment experience } \\
\hline None & 82.8 & 73.1 & 69.9 & 57.5 & 63.7 & 81.0 & 73.7 \\
\hline At one census & 14.0 & 19.2 & 21.3 & 26.6 & 24.7 & 16.8 & 20.6 \\
\hline At more than one census & 3.3 & 7.7 & 8.8 & 15.9 & 11.7 & 2.2 & 5.7 \\
\hline \# Men in unweighted sample & 9,918 & 3,562 & 7,600 & 4,174 & 5,684 & 3,114 & 3,223 \\
\hline $\begin{array}{l}\text { \# Women in } \\
\text { unweighted sample }\end{array}$ & 9,195 & 3,441 & 7,451 & 4,002 & 5,528 & 2,990 & 2,969 \\
\hline
\end{tabular}

Distributions refer to percentages of total risk time for men. Distributions for women are highly similar Socio-economic background, Homeownership background, Family background, and Number of siblings are measured at age 10-14 years. Educational level is measured at age 30-34 years. Civil status and Unemployment experience are summary measures representing ages 20-24, 25-29 and 30-34 years 


\section{Results}

Results of the Cox regressions are reported in a stepwise fashion. Each estimate as reported here gives the relative difference in death rates as compared with death rates in the reference group. To facilitate readability with regard to the parameter patterns, which are our primary focus, confidence intervals are given separately in the Appendix.

We start by reporting results from models that account only for each person's geographic ancestry (population group and birth region) and birth cohort (Table 3). For all-cause mortality represented by the first column, we can see that Finnish speakers born in Western Finland have death rates that are two times as high as those of Swedish speakers born in the Coastal area, people born in Northern Finland 2.5 times as high, and those born in Eastern Finland 2.8 times as high. Also Finnish speakers born in the Coastal area, and Swedish speakers and Finnish speakers born in the Helsinki area, have relatively high mortality rates, or roughly twice those of people in the reference group.

For cause-specific mortality, the results are in accordance with the pattern observed in Fig. 2. Regional variation in all-cause mortality manifests primarily in alcohol-related mortality and in suicides. Finnish speakers born in Western Finland have a risk of alcohol-related mortality that is almost three times as high as that of Swedish speakers born in the Coastal area, people born in Northern Finland 3.8 times as high, and those born in Eastern Finland 5.9 times as high. Also within the Swedish-speaking group there is substantial variation, however. Swedish speakers born in the Helsinki area have almost five times as high alcohol-related mortality as those born in the Coastal area. Separating these two groups implies that the overall variation in alcohol-related mortality is larger than the Swedish-Finnish differential found by previous research (Blomgren et al. 2004). Thus it appears quite clear that mortality within the Helsinki area in particular is interrelated with environmental factors outside the scope of this paper (cf. Valkonen and Kauppinen 2001; Galea et al. 2005). Social problems appear important elements on this concern, considering that also women born in the Helsinki area have high risks of mortality due to alcohol-related causes, suicides, and other external causes, respectively (cf. Fig. 1). Domestic violence constitutes the largest share of all deaths in the latter category (Kauppila 2003; Statistics Finland 2007e).

The overall pattern for suicidal deaths is fairly similar to that for alcohol-related mortality in the sense that there is a clear South-West to North-East pattern. As compared with Swedish speakers born in the Coastal area, Finnish speakers born in Western Finland have 1.6 times as high suicide rates, those born in Northern Finland three times as high, and those born in Eastern Finland 3.1 as high. Again, Swedish speakers born in the Helsinki area have markedly high death rates, and even somewhat higher than Finnish speakers born in the same area.

In cardiovascular diseases there is a clear level difference between Swedish speakers and Finnish speakers, which puts the latter at mortality rates that are between two and four times as high as those of the former. For other diseases the pattern is the same, albeit less marked. As compared with Swedish speakers born in the Coastal area, Finnish speakers have about twice as high death risks. It should be noted, however, that confidence intervals of the parameters are wide. 
Table 3 Relative mortality risks for main causes of death in ages 35-48 years; population group and birth region

\begin{tabular}{|c|c|c|c|c|c|c|c|c|c|}
\hline & \multicolumn{6}{|l|}{ Men } & \multicolumn{3}{|c|}{ Women } \\
\hline & $\begin{array}{l}\text { All } \\
\text { causes }\end{array}$ & $\begin{array}{l}\text { Alcohol- } \\
\text { related }\end{array}$ & $\begin{array}{l}\text { Cardio- } \\
\text { vascular }\end{array}$ & $\begin{array}{l}\text { Other } \\
\text { diseases }\end{array}$ & Suicides & $\begin{array}{l}\text { Other } \\
\text { external }\end{array}$ & $\begin{array}{l}\text { All } \\
\text { causes }\end{array}$ & $\begin{array}{l}\text { Other } \\
\text { diseases }\end{array}$ & $\begin{array}{l}\text { Other } \\
\text { causes }\end{array}$ \\
\hline \multicolumn{10}{|c|}{ Population group + Birth region } \\
\hline $\begin{array}{l}\text { Swedish } \\
\text { speaker in } \\
\text { Coastal area }\end{array}$ & 1.00 & 1.00 & 1.00 & 1.00 & 1.00 & 1.00 & 1.00 & 1.00 & 1.00 \\
\hline $\begin{array}{l}\text { Finnish speaker } \\
\text { in Coastal } \\
\text { area }\end{array}$ & 1.91 & 3.59 & 3.14 & 1.86 & 1.69 & 0.98 & 0.92 & 0.52 & 3.70 \\
\hline $\begin{array}{l}\text { Finnish speaker } \\
\text { in Western } \\
\text { Finland }\end{array}$ & 2.03 & 2.95 & 2.15 & 2.10 & 1.65 & 1.86 & 1.47 & 0.69 & 6.90 \\
\hline $\begin{array}{l}\text { Finnish speaker } \\
\text { in Northern } \\
\text { Finland }\end{array}$ & 2.55 & 3.77 & 3.90 & 1.76 & 2.97 & 1.76 & 1.40 & 0.80 & 5.58 \\
\hline $\begin{array}{l}\text { Finnish speaker } \\
\text { in Eastern } \\
\text { Finland }\end{array}$ & 2.85 & 5.88 & 3.20 & 1.65 & 3.12 & 2.14 & 1.56 & 0.59 & 8.34 \\
\hline $\begin{array}{l}\text { Swedish } \\
\text { speaker in } \\
\text { Helsinki area }\end{array}$ & 1.79 & 4.75 & 0.74 & 1.97 & 2.56 & 0.55 & 0.97 & 0.46 & 4.52 \\
\hline $\begin{array}{l}\text { Finnish speaker } \\
\text { in Helsinki } \\
\text { area }\end{array}$ & 2.29 & 2.94 & 3.16 & 2.22 & 2.33 & 1.72 & 1.43 & 0.37 & 8.79 \\
\hline \multicolumn{10}{|l|}{ Birth cohort } \\
\hline 1956-1960 & 1.00 & 1.00 & 1.00 & 1.00 & 1.00 & 1.00 & 1.00 & 1.00 & 1.00 \\
\hline 1961-1965 & 0.95 & 0.82 & 0.86 & 0.99 & 0.84 & 1.26 & 0.85 & 0.81 & 0.87 \\
\hline 1966-1970 & 0.75 & 0.66 & 1.57 & 0.19 & 0.55 & 1.12 & 0.98 & 1.13 & 0.88 \\
\hline $\begin{array}{l}\text { \# Deaths in } \\
\text { unweighted } \\
\text { sample }\end{array}$ & 639 & 120 & 105 & 112 & 141 & 161 & 250 & 116 & 134 \\
\hline
\end{tabular}

95\% confidence intervals for the parameters are found in the Appendix

Other causes for women refer to all other causes of death except codes 1-26 and 31-40

Also with regard to external causes excluding suicides there is a mortality differential between the two population groups, which say that Finnish speakers have death rates that are almost twice those of Swedish speakers. Specifically noteworthy still is that there is no differential between Swedish speakers born in the Coastal area and Finnish speakers born in the Coastal area. A difference in this respect would have indicated that the mortality gradient is interrelated with cultural factors, as external causes of death excluding suicides can be assumed highly correlated with exposure to hazardous lifestyles (cf. Cubbin et al. 2000).

In women, the low number of deaths makes the results more sensitive to random variation. We are therefore somewhat reluctant to draw any far-reaching conclusions. The results still confirm those of previous research for wider age intervals (Koskinen and Martelin 2003). In overall mortality there is no differential between Swedish 
speakers and Finnish speakers born in the Coastal area, whereas those born in the other regions have approximately 50\% higher death risks. There is substantial variation across the two main causes of death, however. Diseases other than cardiovascular (predominantly neoplasms) are most common among Swedishspeaking women born in the Coastal area, but for all the other causes (predominantly accidents and violence) women in this group have clearly the lowest death rates.

The overall pattern for birth cohort reflects that age-adjusted mortality has decreased over time. There is some variation in this respect across different causes of mortality, which probably has to do with relatively few deaths.

In the second step of the analysis we include individual-level factors representing social background (socio-economic background, homeownership, family, and number of siblings), and in the final third step also for those that measure each person's own social status (educational level, marital status and unemployment experience). The results of the former are reported in Table 4 and those of the latter in Table 5.

The results of Table 4 say that, in spite that living conditions at childhood clearly impact on adult death risks, the mortality variation across birth regions and population groups remains almost unaltered when we account for these circumstances. The overall pattern and sizes of these parameters is almost the same as in Table 3 .

Persons who come from families of higher social class generally have lower death rates than those who come from families of lower social class. Specifically alcohol-related mortality is strongly linked to the socio-economic position of the family. A person who come from a family where the head of the household is an upper-level white-collar, say, has a risk of dying of alcohol-related causes that is more than $60 \%$ lower than that of a person who comes from a blue-collar family. The parameters for "self-employed" and "other" are difficult to interpret as these categories are quite heterogeneous in character. Persons raised in families that do not own their accommodation have higher mortality risks of almost all main causes of death than those who come from house-owning families. Alcohol-related mortality, for instance, increases with approximately $40 \%$ in case of the absence of homeownership. Family background is also relevant. Men who lived with one parent at the age of 10-14 years have about 40\% higher death risks than those who lived with both parents. The impact varies somewhat across causes of death. The most prevalent effect is for external causes of death excluding suicides, which suggest that persons raised in single-parent families are under markedly higher exposure to the risk of accidents and violence than others. The least prevalent effect on this concern is found for suicidal deaths. Persons with no sibling, and those with more than one sibling, generally have higher death risks than those with one sibling. The reasons behind this pattern are not clear. It might reflect some additional variation in living conditions that impact on behaviours, as the most prevalent effects are for external causes of death and alcohol-related mortality.

Finally, in Table 5 we can see that even when the persons' own social status are accounted for, the mortality variation across birth regions and population groups remains almost unaltered. Only for alcohol-related causes, suicides, and other external causes of death, which must be considered at least partly related to health behaviours and hazardous lifestyles, there is some reduction across subgroups. The impact of social background, and particularly of socio-economic background, on 


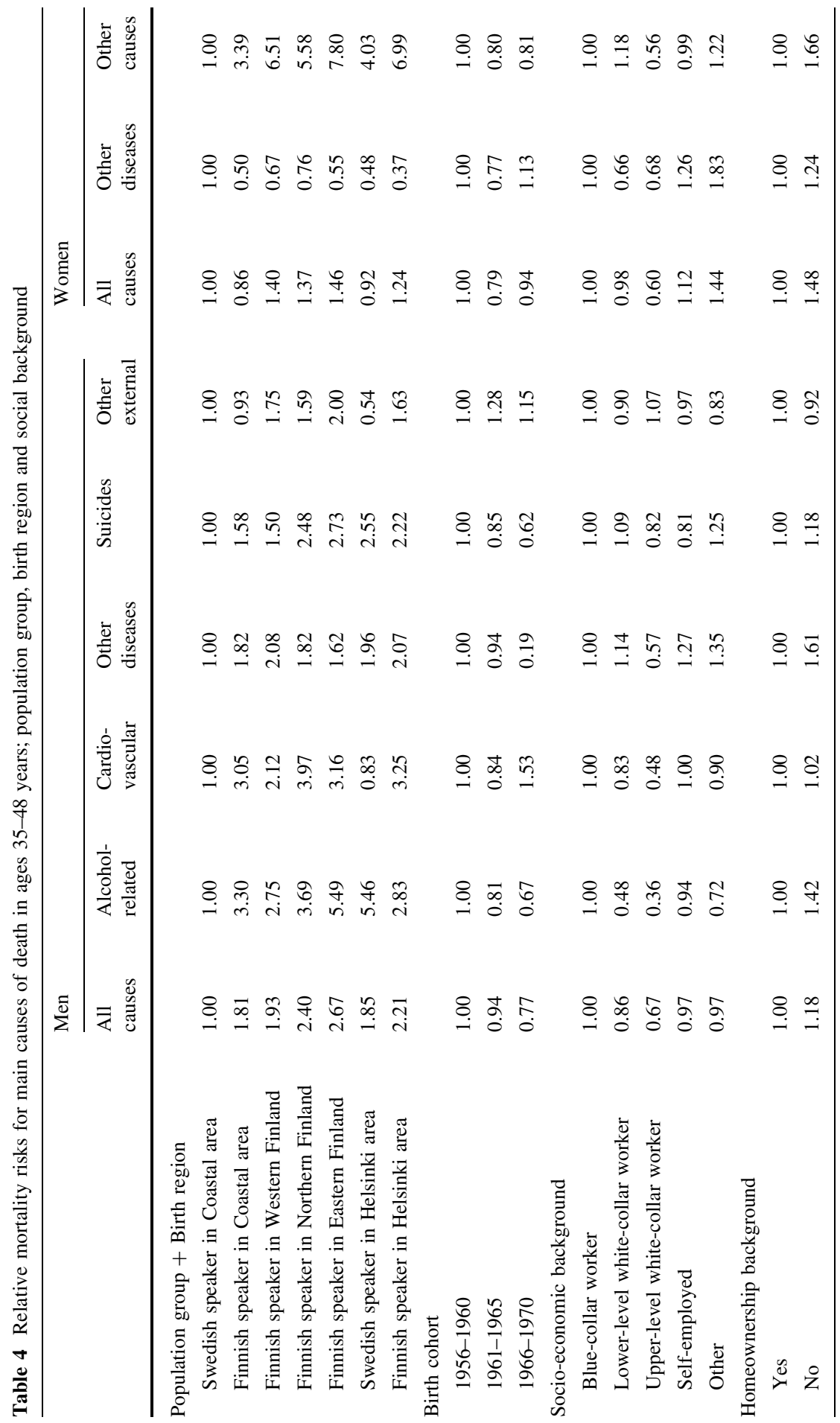




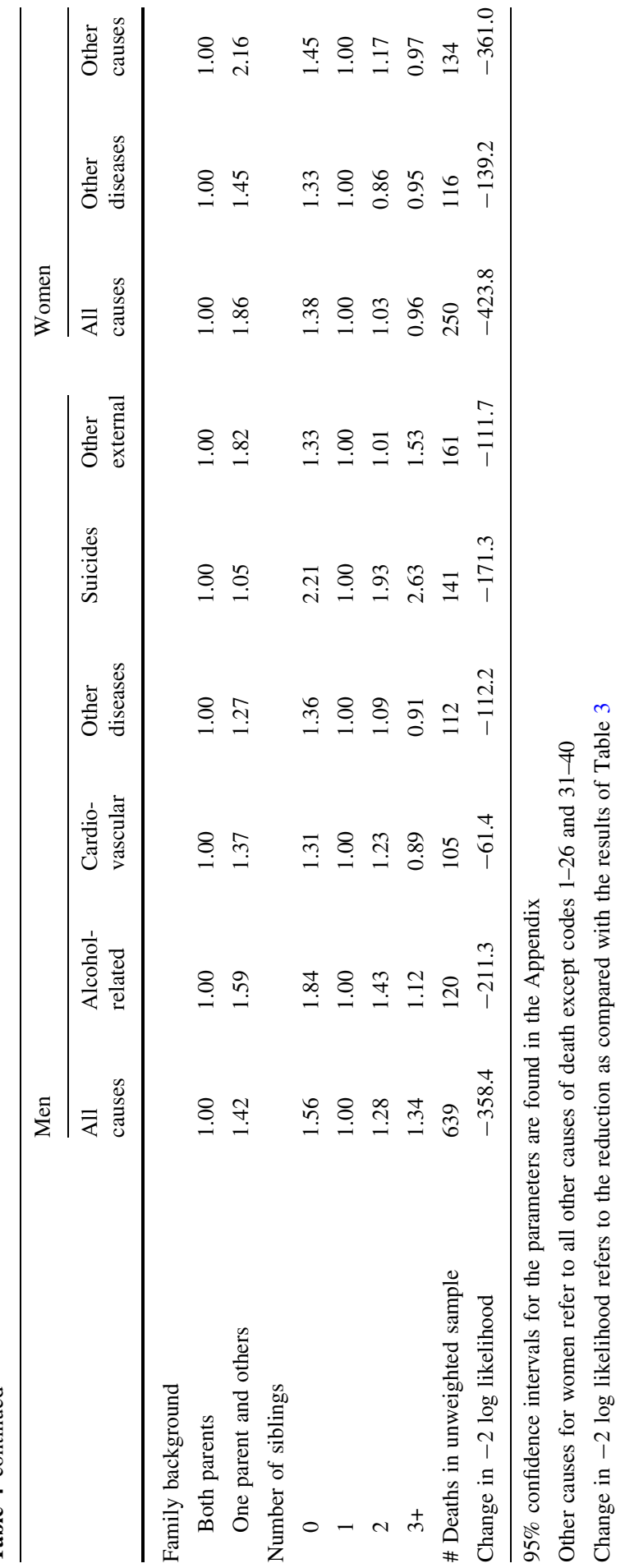




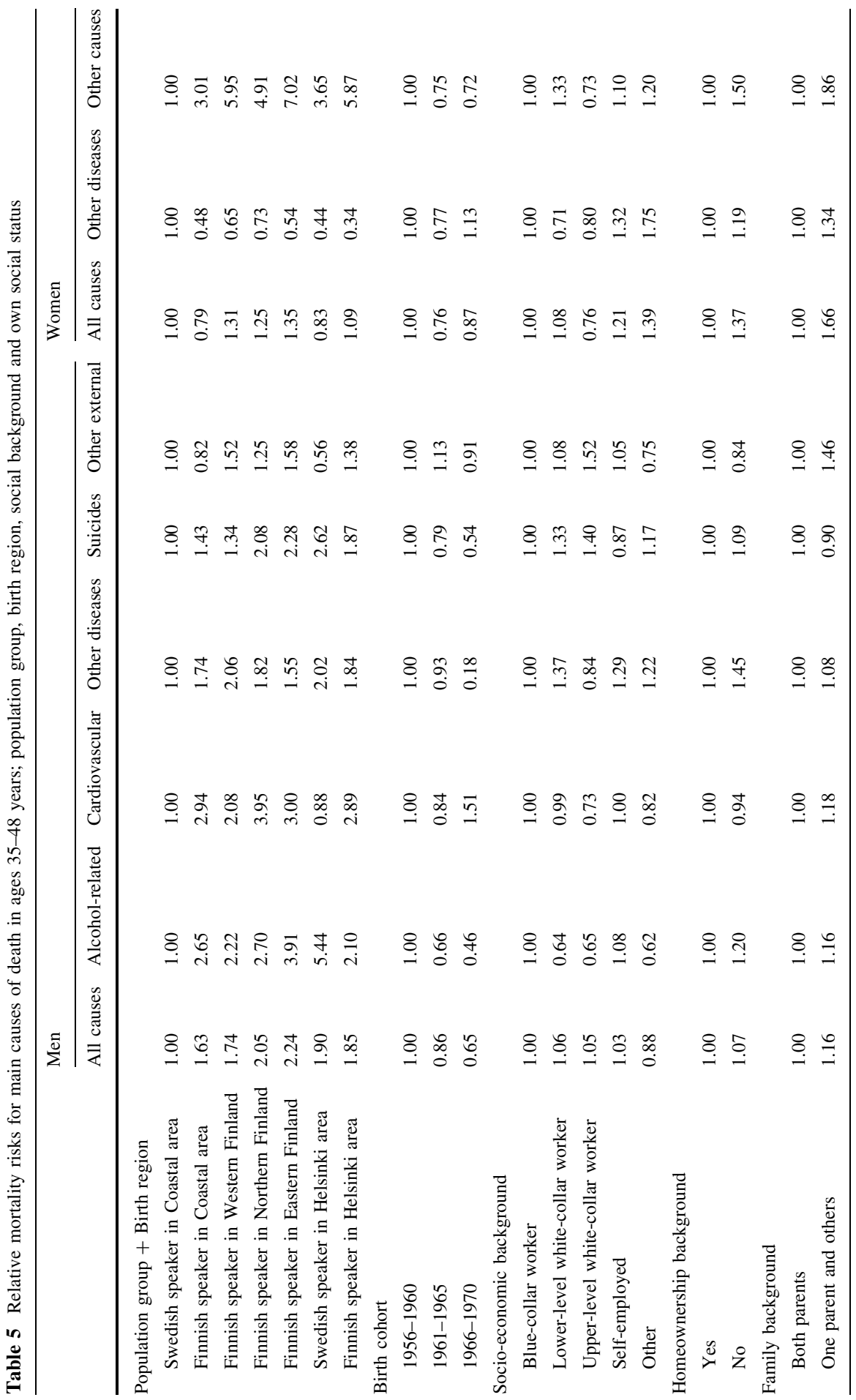




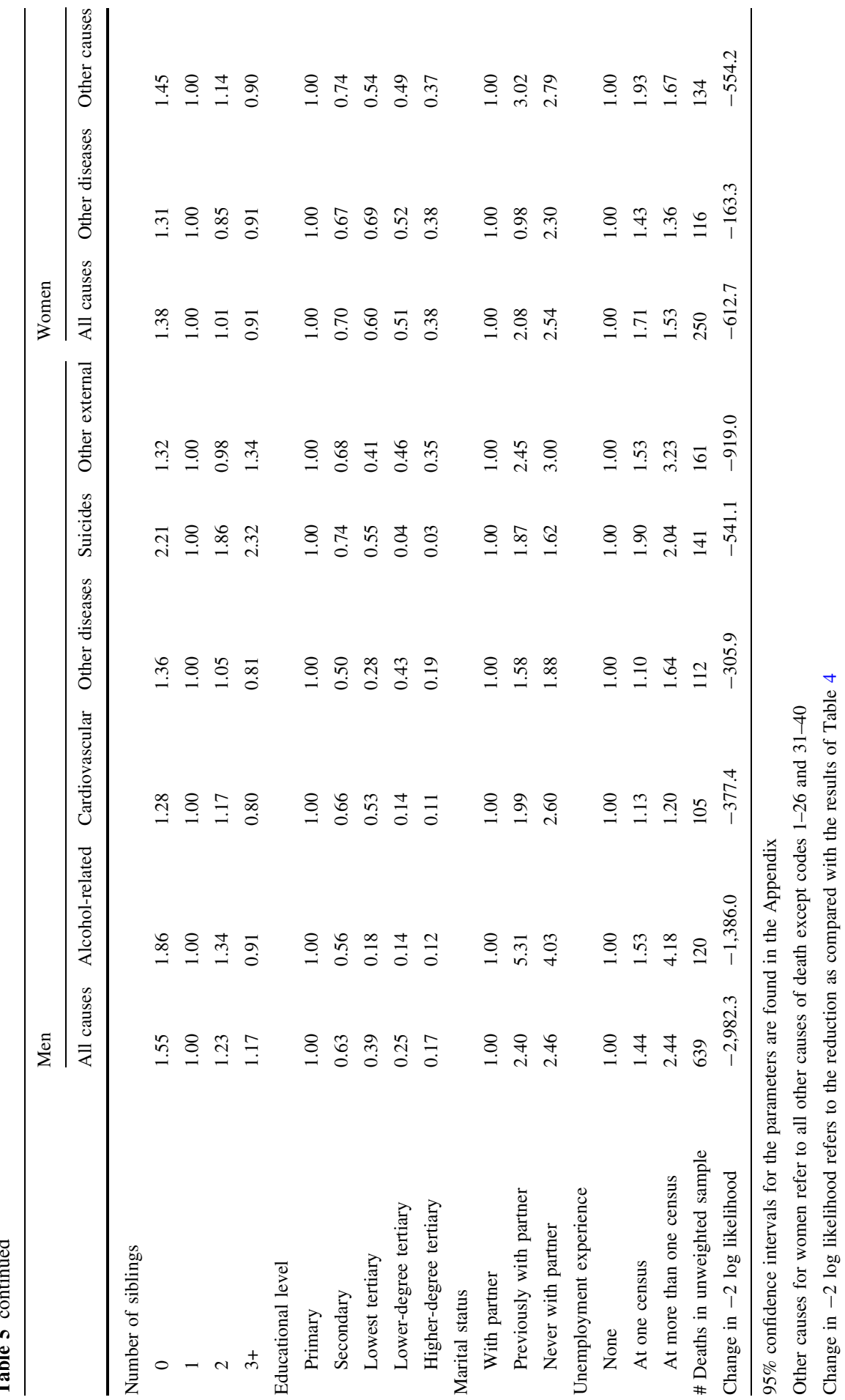


mortality tampers off markedly, however. This is evidently because the variable correlates highly with education, which has a stronger predictive power on mortality. Number of siblings is the only variable for which the estimated parameters change modestly when own social status is included. It consequently seems to reflect some alternative dimension of childhood living conditions, unrelated to the variables that proxy persons' own social status.

In general, these variables have substantial effects on all main causes of mortality. Death rates fall almost consistently over educational level, and the pattern is fairly equal across different causes of death. Thus schooling is an important measure of socio-economic status, but causality obviously also work in both directions in these ages. On the one hand, higher education works as to prevent mortality, e.g. of alcohol-related causes and accidents. On the other hand, people with poor health and thus at increased risk of diseases and suicides, obtain less schooling.

Persons who live with a partner have substantially lower mortality rates than others, which reflect the protective effect of partnership, but also that partnership selects the more healthy people in the population. This appears specifically prominent in women. Those who never had a partner have more than two times higher death risk due to diseases (other than cardiovascular) than those with a partner. For all other causes of death, both divorced women and those previously living in consensual unions, as well as those who never had a partner, have three times higher mortality risks than women with a partner.

A similar argumentation may naturally be applied to labour market history. People with no unemployment experience generally have good health and are thus found to have low mortality rates, but having experienced no unemployment may also protect from poor health behaviours and hazardous ways of living that increase the death risk. Obviously both these variables have a strong social link. The differential in death risks between people with a partner and those without a partner, and between people with no unemployment experience and those with unemployment experience, is the widest for alcohol-related mortality and other external causes of death.

\section{Discussion and Conclusions}

Within many countries, subgroups of the population have been found differing on genetic predisposal (see e.g. Parra et al. 2003; Jackson 2004; Helgason et al. 2005). Geographic ancestry has also in many instances been considered a useful device for making inferences about an individual's ancestry, which may help to predict whether a person carries specific genetic risk factors that influence health (cf. Risch et al. 2002; Edwards 2003; Bamshad 2005; Rosenberg et al. 2005). In this context, genes should not be interpreted at the individual level as the allelic frequency of one individual locus, but in terms of different alleles for several loci that correlate. Hence a single characteristic cannot determine the geographic origin of a person's recent ancestors. As alleles form clusters due to geographic correlation of different loci, variation in genetic predisposal across human beings may instead interrelate with the geographic origins of an individual's recent ancestors. Individuals from geographically proximate regions thus share more recent common ancestry with 
each other than do individuals from more disparate regions. The closer geographic proximity, the stronger is genetic similarity.

The empirical results of this paper may be viewed in light of that argumentation. We find that variation in death rates by geographic ancestry in Finland is only marginally reduced when account is taken for socio-economic and social circumstances at both childhood and adulthood, in spite that these sets of variables have strong effects on mortality. This suggests that variation in genetic predisposal within the population may underlie mortality differentials between Finnish speakers and Swedish speakers. These findings also mirror results from corresponding research conducted on other age groups (Saarela and Finnäs 2006, 2008).

Our analyses of cause-specific deaths, which primarily have been concerned with men as there are few deaths in women, are in line with these conclusions. The interrelation between geographic ancestry and mortality due to alcohol-related causes, as well as suicidal deaths, is partly confounded by socio-economic and social circumstances, but an obvious interrelation with geographic ancestry remains. This might be viewed as an additional support for the genetic hypothesis, as it is known that the liability for developing alcoholism and mental health disorders to some extent is due to genetic factors (Eley and Plomin 1997; McGue 1999; Sullivan et al. 2000; Hesselbrock et al. 2001). We also find that deaths due to external causes excluding suicides, which are expected to be interrelated with hazardous lifestyles via cultural related factors, have the relatively weakest interrelation with geographic ancestry. The impact of geographic ancestry on deaths due to diseases, which hardly can be attributed to lifestyles in the working ages under study here, are not affected when we account for social and socio-economic confounders. This is in support of the fact that a number of non-cardiovascular diseases are concentrated to smaller spatial areas in Finland, and thus presumably to a family-history of the disease (Norio 2003). Variation in deaths due to cardiovascular diseases might be given a similar interpretation, as health behaviours cannot reasonably lead to mortality at these ages.

Throughout much of human history geographic barriers have precluded random mating, which has generated small differences in polymorphism frequencies among the groups that were separated (Bamshad 2006). In addition to large spatial distances and early historical nation borders, language is believed to have worked as an additional such barrier in Finland (Virtaranta-Knowles et al. 1991). This might help to explain why the two population groups differ so markedly in life expectancy, even when one account is taken for a number of detailed structural confounders, as we have done here. More detailed analyses than ours, which explicitly control for biological fundamentals as well as health behaviours, are required before this potentially important genetic link can be established. The interaction between genetic predisposal and environment has drawn increased attention in medical research (Lagercrantz 2007), saying that many genes are not expressed in the phenotype if not triggered by environmental factors. Geographic ancestry is one important element in this context, which should be recognised when developing and implementing public health policies.

Acknowledgements Comments from two anonymous referees and participants at the 18th Nordic Conference in Social Medicine and Public Health are gratefully acknowledged. 


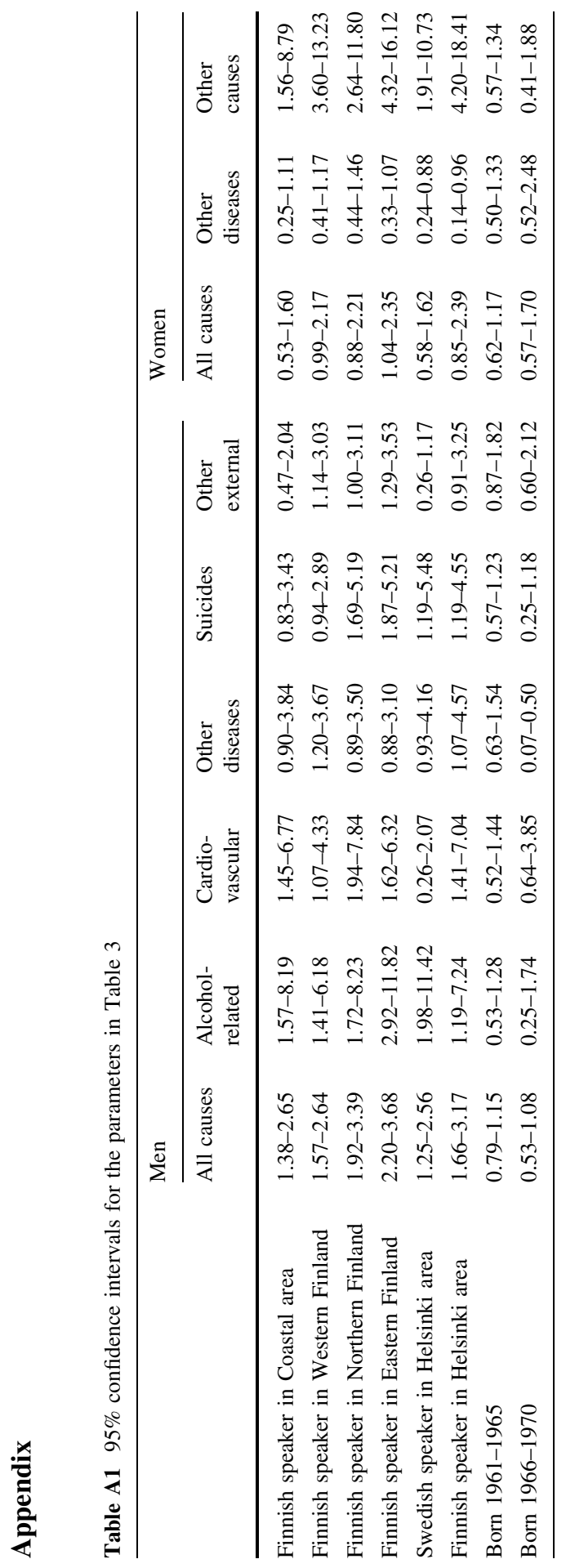




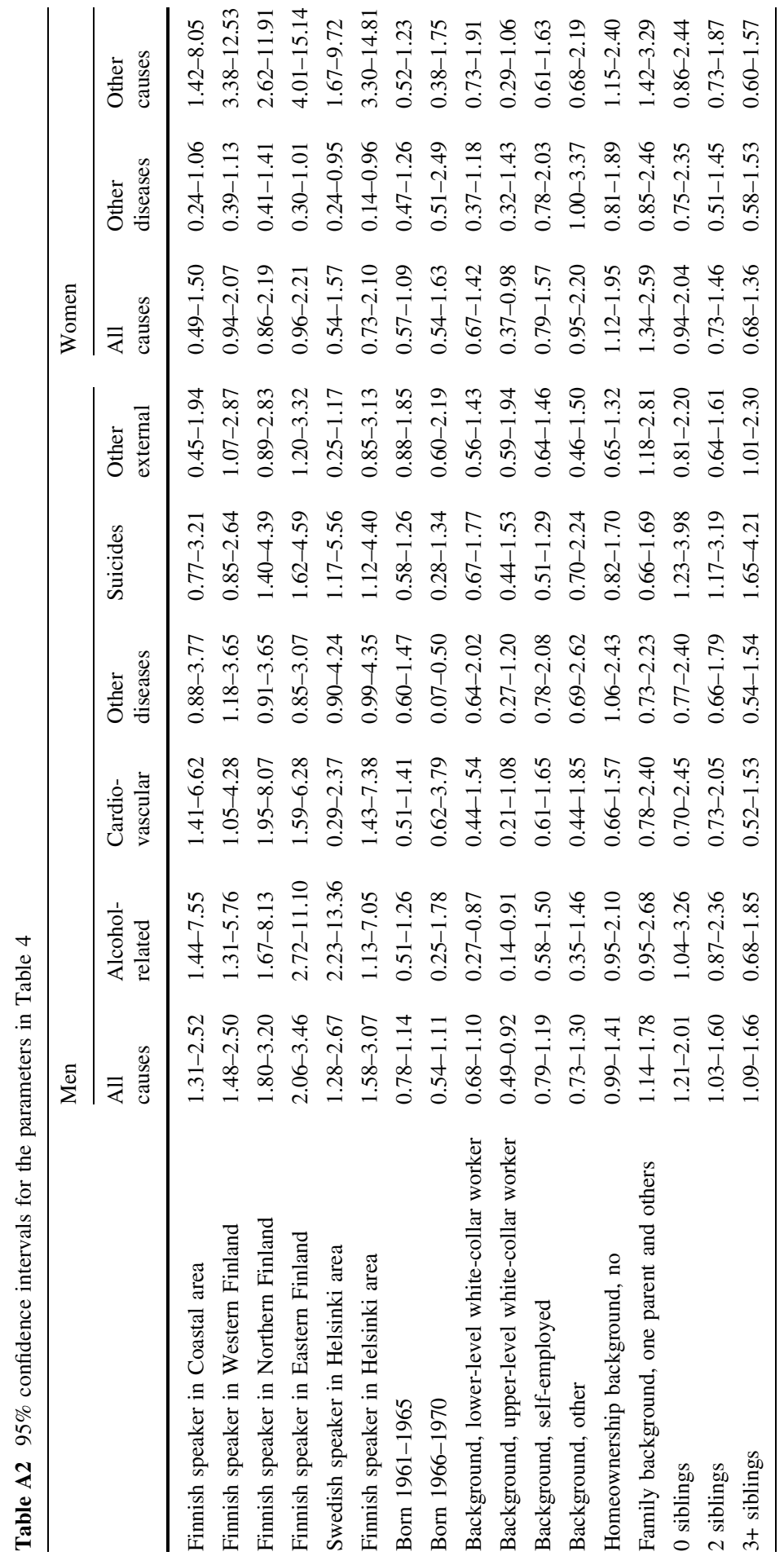




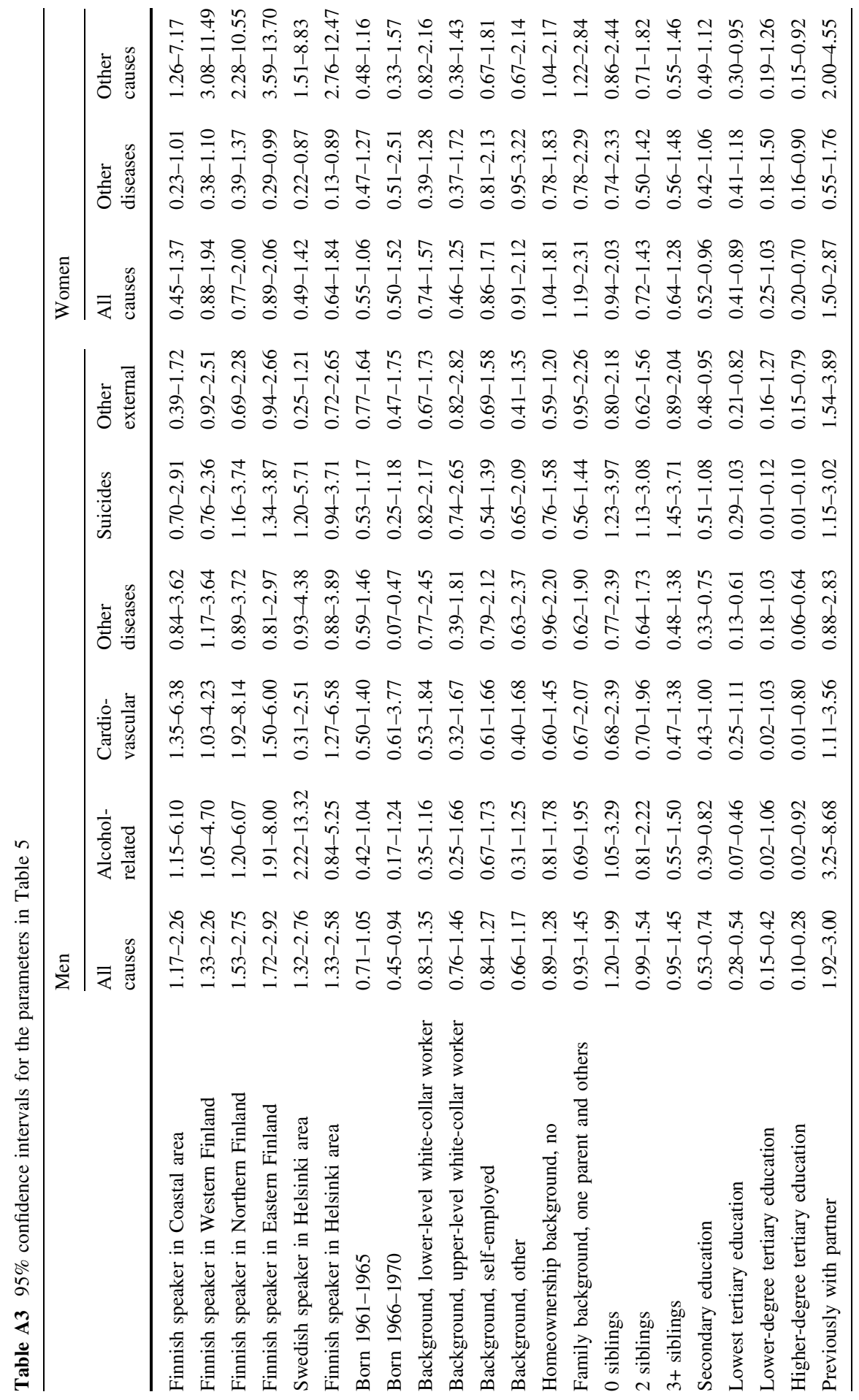




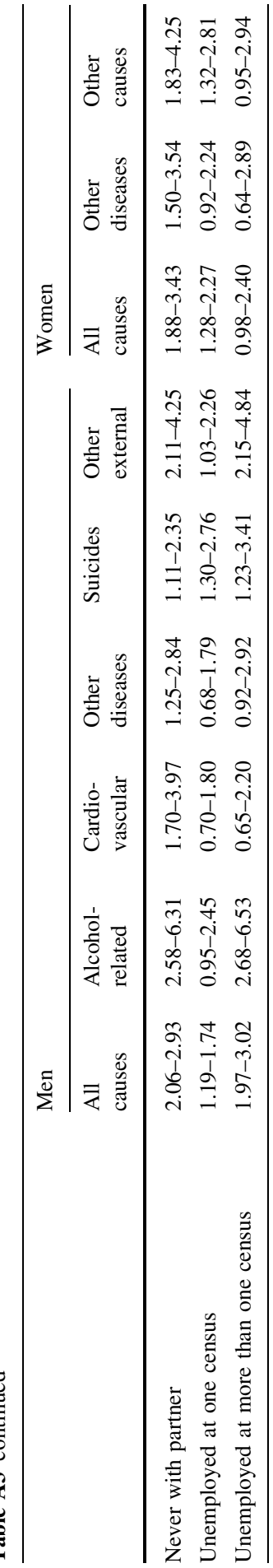




\section{References}

Bamshad, M. (2005). Genetic influences on health. Journal of the American Medical Association, 294, 937-946.

Bamshad, M. (2006). Race and genetic influences on health - reply. Journal of the American Medical Association, 295, 385.

Bartley, M. (1994). Unemployment and ill health: Understanding the relationship. Journal of Epidemiology and Community Health, 48, 333-337.

Blomgren, J., Martikainen, P., Mäkelä, P., \& Valkonen, T. (2004). The effects of regional characteristics on alcohol-related mortality - a register-based multilevel analysis of 1.1 million men. Social Science \& Medicine, 58, 2523-2535.

Cubbin, C., LeClere, F. B., \& Smith, G. S. (2000). Socioeconomic status and injury mortality: Individual and neighbourhood determinants. Journal of Epidemiology and Community Health, 54, 517-524.

Edwards, A. W. F. (2003). Human genetic diversity: Lewontin's fallacy. BioEssays, 25, 798-801.

Eley, T. C., \& Plomin, R. (1997). Genetic analyses of emotionality. Current Opinion in Neurobiology, 7 , 279-284.

Eriksson, A. W. (1973). Genetic polymorphisms in Finno-Ugrian populations. Israel Journal of Medical Sciences, 9, 1156-1170.

Eriksson, A. W., Partanen, K., Frants, R. R., Pronk, J. C., \& Kostense, P. J. (1986). ABH secretion polymorphism in Icelanders, Åland Islanders, Finns, Finnish Lapps, Komi and Greenland Eskimos: A review and new data. Annals of Human Biology, 13, 273-285.

Galea, S., Freudenberg, N., \& Vlahov, D. (2005). Cities and population health. Social Science \& Medicine, 60, 1017-1033.

Helgason, A., Yngvadóttir, B., Hrafnkelsson, B., Gulcher, J., \& Stefánsson, K. (2005). An Icelandic example of the impact of population structure on association studies. Nature Genetics, 37, 90-95.

Hesselbrock, V., Begleiter, H., Porjesz, B., O’Connor, S., \& Bauer, L. (2001). P 300 event-related potential amplitude as an endophenotype of alcoholism - evidence from the collaborative study on the genetics of alcoholism. Journal of Biomedical Science, 8, 77-82.

Hu, Y., \& Goldman, N. (1990). Mortality differentials by marital status: An international comparison. Demography, 27, 233-250.

Jackson, F. L. C. (2004). Human genetic variation and health: New assessment approaches based on ethnogenetic layering. British Medical Bulletin, 69, 215-235.

Kajanoja, P. (1972). A contribution to the physical anthropology of the Finns. Annales Academiae Scientiarum Fennicae, Series A, V Medica, 153.

Kauppila, R. (2003). Sudden and unexpected natural and violent deaths in females in comparison to deaths in males. A medico-legal autopsy study in the province of Southern Finland during the years 1985, 1992, and 1999. Doctoral Dissertation, University of Helsinki, Department of Forensic Medicine.

Korkiasaari, J., \& Söderling, I. (1994). Muuttoliike. In S. Koskinen, T. Martelin, I.-L. Notkola, V. Notkola, \& K. Pitkänen (Eds.), Suomen Väestö (pp. 226-264). Hämeenlinna: Gaudeamus.

Koskinen, S. (1994). Origin of regional differences in mortality from ischaemic heart disease in Finland. Doctoral Dissertation. Research Reports, No. 41. National Research and Development Centre for Welfare and Health, Jyväskylä.

Koskinen, S., \& Martelin, T. (1994). Kuolleisuus. In S. Koskinen, T. Martelin, I.-L. Notkola, V. Notkola, \& K. Pitkänen (Eds.), Suomen Väestö (pp. 150-225). Hämeenlinna: Gaudeamus.

Koskinen, S., \& Martelin, T. (2003). Why is mortality low among the Swedish-speaking minority in Finland? Yearbook of Population Research in Finland, 39, 15-32.

Lagercrantz, H. (2007). Gene-environment interaction is now hype. Acta Paediatrica, 96, 1253.

Langford, I. H., \& Bentham, G. (1996). Regional variations in mortality rates in England and Wales: An analysis using multi-level modelling. Social Science \& Medicine, 42, 897-908.

Lunetta, P., Penttilä, A., \& Sarna, S. (2001). The role of alcohol in accident and violent deaths in Finland. Alcoholism: Clinical \& Experimental Research, 25, 1654-1661.

Luy, M. (2004). Mortality differences between Western and Eastern Germany before and after reunification. A macro and micro level analysis of developments and responsible factors. Genus, 60 , 99-141.

Martelin, T. (1994). Differential mortality at older ages. Doctoral Dissertation, Publications of the Finnish Demographic Society, No. 16, Helsinki. 
Martikainen, P. T., \& Valkonen, T. (1996). Excess mortality of unemployed men and women during a period of rapidly increasing unemployment. Lancet, 348, 909-912.

McGue, M. (1999). The behavioral genetics of alcoholism. Current Directions in Psychological Science, $8,109-115$.

Norio, R. (2003). Finnish disease heritage. Human Genetics, 112, 441-526.

Parra, F. C., Amado, R. C., Lambertucci, J. R., Rocha, J., Antunes, C. M., \& Pena, S. D. J. (2003). Color and genomic ancestry in Brazilians. Proceedings of the National Academy of Sciences of the United States of America, 100, 177-182.

Pensola, T. H. (2003). From past to present: Effect of lifecourse on mortality, and social class differences in mortality in middle adulthood. Doctoral Dissertation. Yearbook of Population Research in Finland, 39, Supplement.

Pitkänen, K., Koskinen, S., \& Martelin, T. (2000). Kuolleisuuden alue-erot ja niiden historia. Duodecim, 116, 1697-1710.

Rosenberg, N. A., Mahajan, S., Ramachandran, S., Zhao, C., Pritchard, J. K., \& Feldman, M. W. (2005). Clines, clusters, and the effect of study design on the inference of human population structure. PloS Genetics, 1, e70.

Risch, N., Burchard, E., Ziv, E., \& Tang, H. (2002). Categorisation of humans in biomedical research: Genes, race and disease. Genome Biology, 3, 1-12.

Saarela, J. (2006). Wealth in two ethnic groups: The role of internal migration background. Finnish Yearbook of Population Research, 42, 43-64.

Saarela, J., \& Finnäs, F. (2005a). Mortality inequality in two native population groups. Population Studies, 59, 313-320.

Saarela, J., \& Finnäs, F. (2005b). Geographical extraction and the Finnish-Swedish health differential in Finland. Yearbook of Population Research in Finland, 41, 61-73.

Saarela, J., \& Finnäs, F. (2006). Regional mortality variation in Finland: A study of two population groups. Genus, 62, 169-211.

Saarela, J., \& Finnäs, F. (2008). Cause-specific mortality at young ages: Lessons from Finland. Health \& Place, 14, 265-274.

Sahi, T. (1974). Lactose malabsorption in Finnish speaking and Swedish speaking populations in Finland. Scandinavian Journal of Gastroenterology, 9, 303-308.

Sauli, H. (1979). Ammatti ja kuolleisuus 1971-75. Research Reports, No. 54. Statistics Finland, Helsinki.

Simpura, J. (1990). Hur dricker finlandssvensken? Finska Läkarsällskapets Handlingar, 150, 168-170.

Statistics Finland. (2007a). Causes of death. http://pxweb2.stat.fi/database/PX-Web\%20StatFin/Terveys/ Kuolemansyyt/Kuolemansyyt.asp. Accessed 4 April 2007.

Statistics Finland. (2007b). Population. http://pxweb2.stat.fi/database/V\%E4est\%F6/V\%E4est\% F6rakenne/V\%E4est\%F6rakenne.asp. Accessed 4 April 2007.

Statistics Finland. (2007c). Causes of death and population: Swedish speakers (Complementary data, not available online). Accessed 4 April 2007.

Statistics Finland. (2007d). Data description. Väestölaskentojen pitkittäistiedosto 1970-1995. http://www. stat.fi/meta/rekisteriselosteet/rekisteriseloste_vaestolaskenta70-95.html. Accessed 4 April 2007.

Statistics Finland. (2007e). Victims of violence by perpetrator, age and sex 1998-2005. http://pxweb2. stat.fi/database/StatFin/ter/ksyyt/ksyyt_fi.asp. Accessed 4 April 2007.

Sullivan, P. F., Neale, M. C., \& Kendler, K. S. (2000). Genetic epidemiology of major depression: Review and meta-analysis. American Journal of Psychiatry, 157, 1552-1562.

Valkonen, T. (1987). Male mortality from ischaemic heart disease in Finland: Relation to region of birth and region of residence. European Journal of Population, 3, 61-83.

Valkonen, T., \& Kauppinen, T. M. (2001). Miesten kuolleisuuden alue-erot ja sosiaalinen segregaatio pääkupunkiseudulla. Kvartti, (1), 7-21.

Valkonen, T., Martelin, T., Rimpelä, A., Notkola, V., \& Savela, S. (1992). Sosioekonomiset kuolleisuuserot 1981-90. SVT Väestö, No. 8. Helsinki.

Virtaranta-Knowles, K., Sistonen, P., \& Nevanlinna, H. R. (1991). A population genetic study in Finland: Comparisons of the Finnish- and Swedish-speaking populations. Human Heredity, 41, 248-264.

Workman, P. L., Mielke, J. H., \& Nevanlinna, H. R. (1976). The genetic structure of Finland. American Journal of Physical Anthropology, 44, 341-367. 